\title{
Can appendix bending angle be an additional finding to detect acute appendicitis on MDCT?
}

\section{Akut appendisitin ÇKBT tanısında appendiks bükülme açısı ek bir tanısal bulgu olabilir mi?}

Nurcan Ertan ${ }^{1 *}$, Tuba Akdağ $^{1}$, Irmak Durur Subasi ${ }^{1}$, İsmail Oskay Kaya ${ }^{2}$, Baki Hekimoğlu ${ }^{1}$

${ }^{1}$ Department of Radiology, University of Health Sciences, Diskapi Yildirim Beyazit Training and Research Hospital, Ankara, Turkey

2 Department of General Surgery, University of Health Sciences, Diskapi Yildirim Beyazit Training and Research Hospital, Ankara, Turkey

\section{ABSTRACT}

Aim: Computed tomography (CT) is frequently used as an imaging modality in the evaluation of acute appendicitis. The most frequently used measurement to detect acute appendicitis is maximal outer diameter of appendix on CT and several studies have reported other $\mathrm{CT}$ findings of acute appendicitis, such as thickness of the appendiceal wall, appendiceal wall enhancement, peri-appendiceal free fluid, peri-appendiceal inflammation, peri-appendiceal lymph node, appendicolith and cecal wall thickening. We investigated the value of the appendix bending angle (ABA) as an additional and novel finding in the diagnosis of acute appendicitis.

Methods: This retrospective study was conducted after the local ethics committee's approval. 52 consecutive patients who underwent appendectomies were assigned to the study group. The patients, who underwent abdominopelvic CT for any other reason than acute abdomen, were included as control group.

Results: The mean age of the appendicitis group was $41.9 \pm 16.0$; male predominance was present $(n=32,61.5 \%)$. Peri-appendiceal inflammation was seen in $65.4 \%$, peri-appendiceal lymph node was seen in $73.1 \%$ and appendicolith was present in $9.6 \%$ of the appendicitis group. The mean ABA was $103.0 \pm 15.9$ degree in study group and $118.8 \pm 23,8$ degree in control group respectively $(p<0.001)$. The sensitivity of ABA was calculated as $76.9 \%$ and the specificity was $58.3 \%$ at 113.15 degree which is the best cut-off point calculated by ROC curve. There was no appendicitis over 142.3 degrees.

Conclusion: ABA can be used as an additional finding which is decreased in acute appendicitis.

Key words: acute, appendicitis, angle, multidetector computed tomography

\section{ÖZ}

Amaç: Bilgisayarlı tomografi (BT), akut apandisit tanısında sık kullanılan bir görüntüleme yöntemidir. Akut apandisiti saptamak için BT'de en sık kullanılan ölçüm; apendiks en geniş dış çapının transvers düzlemde ölçümüdür. Birçok çalışma apendiks duvar kalınlığı, apendiks duvar kontrastlanması, peri-apendiküler serbest sIVISI, peri-apendiküler enflamasyon, peri-apendiküler lenf nodu, apendikolit ve çekum duvar kalınlaşması gibi akut apandisitin diğer BT bulgularını bildirimiş̧tir. Biz çalışmamızda akut apandisit tanısında apendiks bükülme açııının (ABA) tanıya ek ve yeni bir bulgu olarak katkısını araştırdık.

Yöntemler: Bu retrospektif çalışma enstitüden etik kurul onayı alındıktan sonra yapıldı. Çalışma grubuna ardışık tarihlerde apendektomi yapılan 52 hasta alındı. Akut batın dışı nedenlerle abdominal BT çekilen hastalardan da kontrol grubu oluşturuldu. Bulgular: Akut apandisit grubunun yaş ortalaması $41.9 \pm 16.0$ idi. Erkek hastalar çoğunluktaydı ( $n=32, \% 61.5)$. Akut apandisit grubunda peri-apendiküler inflamasyon $\% 65.4$, peri-apendiküler lenf nodu $\% 73.1$ ve apendikolit \%9.6 oranlarında pozitif bulundu. Ortalama ABA, çalışma grubunda $103.0 \pm 15.9$ derece, kontrol grubunda ise $118.8 \pm 23.8$ derece idi $(p<0.001)$. ABA'nın duyarlıı̆ı $\% 76.9$ olarak hesaplandı ve özgüllüğü ROC eğrisi ile hesaplanan en iyi kesme noktası olan 113.15 derecede \% 58.3 idi. 142.3 derecenin üzerinde akut apandisit saptanmadı.

Sonuç: ABA'nın azalmış olması akut apendisit tanısında ek bir bulgu olarak kullanılabilir.

Anahtar Kelimeler: akut, apendisit, açı, çok kesitli bilgisayarlı tomografi

Received: 19.09.2019 Accepted: 30.12.2019 Published (Online):02.03.2020

* Corresponding author: Nurcan Ertan, Department of Radiology, University of Health Sciences, Diskapi Yildirim Beyazit Training and Research Hospital, Ankara,Turkey. Phone: +905322277579 e-mail: n-ertan2000@hotmail.com

ORCID: 0000-0002-0941-0757

To cited: Ertan N, Akdag T, Subası ID, Kaya IO, Hekimoglu B. Can appendix bending angle be an additional finding to detect acute appendicitis on MDCT? Acta Med. Alanya 2020;4(1):76-81. doi:10.30565/medalanya.622116 


\section{INTRODUCTION}

A cute appendicitis is the most common cause of acute abdomen that requires surgery, with an estimated lifelong risk of $8.6 \%$ in men and $6.7 \%$ in women [1]. It is often regarded as a disease of the young population with a peak incidence in the second and third decades of life [1]. Appendectomy is generally accepted as a first-line treatment for non-complicated acute appendicitis [2]. Plain radiography, ultrasonography and computed tomography and even magnetic resonance imaging have all been used in diagnosis.

Computed tomography (CT) has been frequently used as an imaging modality in the evaluation of acute appendicitis and has improved the diagnostic ability, leading to a significant reduction in the number of negative appendectomies [3]. The use of CT has led not only to a substantial decrease in the rate of unnecessary appendectomies, but also to a concomitant decrease in the perforation rate [4]. With reported sensitivities of up to $83-99 \%$ and specificities of $92-99 \%$, CT plays a major role in the clinical decision-making process in acute appendicitis and is considered as a first-line and rapid imaging modality in the diagnostic workup for suspected acute appendicitis [5,6]. A normal appendix can be identified in $73-82 \%$ of patients with thin-section axial CT abdomen; also, it can be increased to $93 \%$ by using 16 -slice CT and multiplanar reformation images [7]. Additionally, using a 64-slice multi-detector CT (MDCT) with coronal reformations can increase the identification rate up to $98.5 \%[8]$.

Several studies have reported CT findings of acute appendicitis [9-12]. However, there are no reported conflicting results about the appendix bending angle (ABA) and no available data as to whether a cut-off point influence $A B A$ in adults, with or without acute appendicitis. In this study we hypothesized that as an empty small intestinal segment; the appendix gets rigid and bends towards the cecum at an acute angle. However, a non-inflamed appendix has a relax lining and positioned across the cecum at an obtuse angle. Establishing normal and abnormal parameters for ABA is important because in subtle cases this angle can be helpful for the correct diagnosis. Furthermore, we believe ABA measures can be a precursor for an inflamed appendix and thus, in this study, we investigated signs of inflamed and noninflamed appendix on MDCT and reference values for $A B A$ in symptomatic and asymptomatic adults, using reformatted $C T$ imaging.

\section{MATERIAL AND METHODS}

This retrospective study was approved by the local ethics committee of Diskapi Yildirim Beyazit Training and Research Hospital (approval date: 16.01.2017, no: 34/26). From January 2016 to October 2016, 63 patients who underwent appendectomy (laparoscopic or open) for suspected acute appendicitis and diagnosed as acute appendicitis surgically, were included the study. Of these, 11 patients were excluded for the following reasons: preoperative CT was not performed $(n=4)$, CT scanning without using intravenous contrast media (2), complicated appendicitis (abscess, phlegmon, and focal defect in the appendiceal wall, $n=3$ ) and poor CT image quality $(n=2)$. In total, 52 consecutive patients were included in the study group. For the aim of the control group, patients who underwent contrast enhanced abdominopelvic CT for causes other than acute abdomen were enrolled consecutively between the same dates of the study group.

\section{MDCT imaging}

MDCT examinations were performed with a 128-detector row CT machine (GE Optima 660 SE 64 Detector 128-slice CT, General Electric Medical Systems, Milwaukee, WI). CT protocols were based on the following: effective level of 140-175 mAs, $120 \mathrm{kVp}, 0.625$ collimation, 5-mm thickness reconstruction at $5-\mathrm{mm}$ intervals, 0.5 -second rotation time. $100-120 \mathrm{ml}$ iodinated contrast medium was injected via the antecubital vein at a rate of $3 \mathrm{~mL} / \mathrm{second}$, with a delay of 60 seconds between contrast administration and data acquisition given at a rate of $3-3.5 \mathrm{~mL} / \mathrm{s}$. We did not use enteric contrast material, as the need for it is questionable according to recent studies $[13,14]$. Images were acquired from the dome of the diaphragm through the pubic symphysis. Both transverse, sagittal and coronal reconstruction images were obtained. Soft tissue kernel was used and the reconstruction increment was 0.625 $\mathrm{mm}$. 
Image analyses: Two abdominal radiologists who were blinded to the histopathologic and surgical findings evaluated in consensus all images retrospectively. They evaluated the following features: transverse diameter of the appendix, thickness of the appendiceal wall, appendiceal wall enhancement, peri appendiceal free fluid, peri appendiceal inflammation, existence of periappendiceal lymph node, appendicolith and cecal wall thickening [15]. The transverse diameter of the appendix and thickness of the appendiceal wall were measured at maximal short-axis diameter and maximal wall thickness of the inflamed appendix, respectively. Appendiceal wall enhancement was compared to that of the cecal wall and divided into two groups: increased or unincreased [15]. Images were evaluated for ABA on coronal reformat images. $A B A$ was defined as the wide angle between long axis of cecum and long axis of proximal appendix. Figure 1 showed ABA measurement on normal and inflamed appendix. Each observer measured ABA on the same day in separated computers to assess interobserver variation. Additionally, to detect intraobserver variations, observers measured the $A B A$ for the second time in two-week interval. Observers were blinded to their previous measurements. The final measurement of continuous variables were calculated as follows: The mean of the two measurement of the first observer was added to the second observers result and divided into two again [Result $=0.5 \times(($ First look of Observer $1+$ Second look of Observer1) $\times 0.5+$ Observer2)].

Statistical Analyses:

The statistical calculations were performed by "IBM SPSS Statistics for Windows, Version 23.0. Armonk, NY: IBM Corp.". The continuous variables were expressed as mean $\pm \mathrm{sd}$, categorical data was expressed as $\mathrm{n}(\%)$. The normal distribution was determined by histogram and KolmogorovSmirnov test. To compare the mean of two groups that were normally distributed, Student's $t$ Test was used. The categorical parameters were compared by Chi Square test. ROC analysis was used to determine the cut-off points; sensitivity and specificity values were calculated. Correlation of the same raters two judgments was calculated by Pearson Correlation Coefficient and correlation between two radiologists by Kendall's Coefficient of Concordance (the mean value of the first observer compared with the second observer's measurement). All tests was applied as two tailed and the statistical significance level was $p<0.05$.

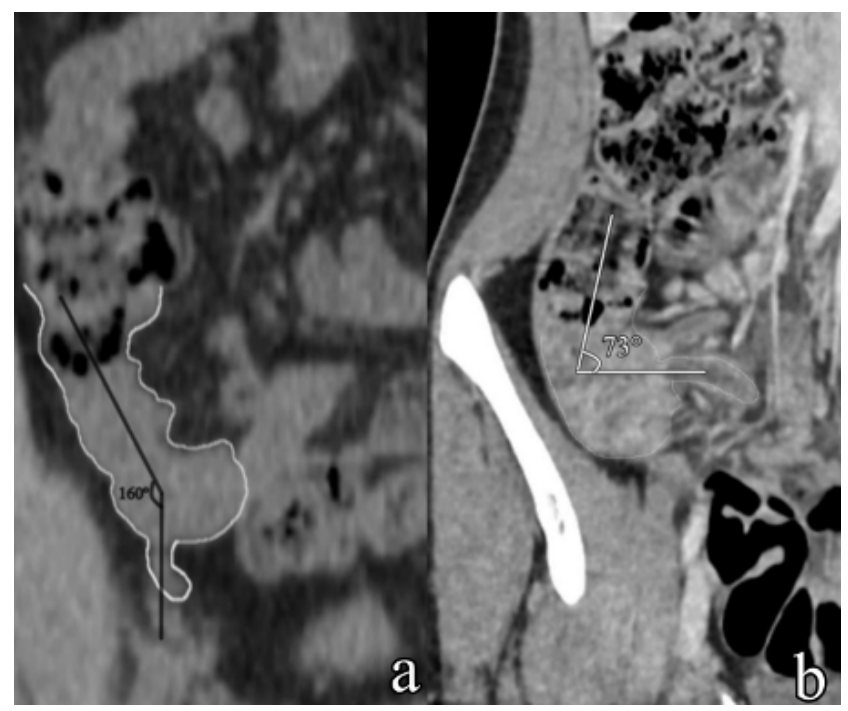

Figure 1: (a) Normal appendix. Appendix bending angle measurement technique in coronal plane (the angle between the vertical line of cecum and appendix) (b) Acute appendicitis. Measurement of ABA in coronal plane.

\section{RESULTS}

The mean age of the appendicitis group was $41.9 \pm 16.0$ (range 18-77) versus the control group was $45.4 \pm 15.2$ (range 18-80). Male predominance was present in the appendicitis group $(n=32$, $61.5 \%$ ) whereas female dominance was present in the control group $(n=27,56.3 \%)$.

The frequency of peri appendiceal inflammation, peri appendiceal lymph node, appendicolith, as well as the means of appendix wall thickness, cecum wall thickness, appendix diameter and $A B A$ and comparison of appendicitis and control group, were given in Table 1.

Peri appendiceal inflammation was present in $65.4 \%$ of the appendicitis group but also in $4.2 \%$ of the control group. It is more frequently observed in appendicitis, but the sensitivity was $65.38 \%$ and the specificity was $95.83 \%$; positive predictive value (PPV) was $94.44 \%$ (81.19\% $98.53 \%$ ), negative predictive value (NPV) was $71.88 \%(63.65 \%$ to $78.86 \%)$.

Peri appendiceal lymph node was present in $73.1 \%$ of the appendicitis group but also in $14.6 \%$ of the control group. It was more frequently 
observed in appendicitis, but the sensitivity was $73.08 \%$ and the specificity was $85.42 \%$; positive predictive value (PPV) was $84.44 \%(72.86 \%$ $91.65 \%$ ), negative predictive value (NPV) was $74.55 \%$ (64.83\% to $82.31 \%)$.

Table 1. Frequency of appendicitis findings and measurements of appendix in appendicitis and control group

\begin{tabular}{|c|c|c|c|c|c|}
\hline & \multicolumn{2}{|c|}{ Appendicitis Group } & \multicolumn{2}{|c|}{ Control Group } & \multirow[t]{2}{*}{$P$} \\
\hline & $\mathrm{n}$ & $\%$ & $\mathrm{n}$ & $\%$ & \\
\hline $\begin{array}{l}\text { Periappendiceal } \\
\text { inflammation }\end{array}$ & 34 & $65,40 \%$ & 2 & $4,20 \%$ & $<0,001$ \\
\hline $\begin{array}{l}\text { Periappendiceal } \\
\text { lymph node }\end{array}$ & 38 & $73,10 \%$ & 7 & $14,60 \%$ & $<0,001$ \\
\hline \multirow[t]{2}{*}{ Appendicolith } & 5 & $9,60 \%$ & - & - & $<0,028$ \\
\hline & mean \pm sd & $\begin{array}{l}(\min - \\
\max )\end{array}$ & & $\begin{array}{l}(\min - \\
\max )\end{array}$ & \\
\hline $\begin{array}{l}\text { Bending angle } \\
\text { (degree) }\end{array}$ & $\begin{array}{l}103,0 \pm \\
15,9\end{array}$ & $\begin{array}{l}(69,5- \\
142,3)\end{array}$ & $\begin{array}{l}118,8 \pm \\
23,8\end{array}$ & $\begin{array}{l}(75,8- \\
160,0)\end{array}$ & $<0.001$ \\
\hline $\begin{array}{l}\text { Appendix di- } \\
\text { ameter (mm) }\end{array}$ & $\begin{array}{l}10,14 \pm \\
1,53\end{array}$ & \begin{tabular}{|l|}
$5,0-$ \\
$13,0)$ \\
\end{tabular} & $\begin{array}{l}4,66 \pm \\
0,46\end{array}$ & $\begin{array}{l}(3,5- \\
5,3) \\
\end{array}$ & $<0.001$ \\
\hline $\begin{array}{l}\text { Appendix wall } \\
\text { thickness (mm) }\end{array}$ & $\begin{array}{l}3,87 \pm \\
0,68\end{array}$ & $\begin{array}{l}(2,23- \\
5,43)\end{array}$ & $\begin{array}{l}2,42 \pm \\
0,29\end{array}$ & $\begin{array}{l}\left(1,88^{-}\right. \\
3,18)\end{array}$ & $<0.001$ \\
\hline $\begin{array}{l}\text { Cecum wall } \\
\text { thickness (mm) }\end{array}$ & $\begin{array}{l}4,35 \pm \\
0,84\end{array}$ & \begin{tabular}{|l}
$(2,48-$ \\
$6,38)$
\end{tabular} & $\begin{array}{l}2,65 \pm \\
0,40\end{array}$ & $\begin{array}{l}(2,00- \\
3,90)\end{array}$ & $<0.001$ \\
\hline
\end{tabular}

Appendicolith was present in $9.6 \%$ of the appendicitis group but in none of the control group. It was observed in appendicitis, but the sensitivity was $96.2 \%$ and the specificity was $100 \%$; positive predictive value (PPV) was $100 \%$, negative predictive value (NPV) was $50.53 \%(48.31 \%$ to $52.74 \%)$.

The mean of appendix wall thickness, cecum wall thickness and appendix diameter were greater in appendicitis group as expressed in Table 2, ROC curve and best cut-off points of these measurements were given in Figure 2. The mean ABA was $103.0 \pm 15.9$ in acute appendicitis group and $118.8 \pm 23.8$ in control group, respectively. The ROC curve of appendix bending angle was showed in Figure 3. Area under curve in ROC analysis was $0.695(0.588-0.801 ; 95 \% \mathrm{Cl})$. Two cut-off points with sensitivity and specificity values were given in Table 2. According to ROC curve the best cut-off of point was 113.15 degrees; at this point the sensitivity was $76.9 \%$ and the specificity was $58.3 \%$ (PPV $66.67 \%$ and NPV $70.00 \%$ ). When we got the cut-off of point as 110 degrees the sensitivity would be $69.2 \%$ and the specificity would be $60.4 \%$ (PPV $65.5 \%$ and NPV $63.6 \%$ ).
As we saw in Table 1, there were no appendicitis cases over the bending angle 142.3 degrees.

Table 2. AUC and cut-off points determined by ROC curve and sensitivity and specificity of these points

\begin{tabular}{|c|c|c|c|c|}
\hline & $\begin{array}{l}\text { AUC* of ROC }{ }^{* *} \\
\text { Curve (Up- } \\
\text { per-Lower } \\
\text { Bound with } 95 \% \\
\mathrm{Cl}^{* *} \text { ) }\end{array}$ & $\begin{array}{l}\text { Cut-off } \\
\text { Point }\end{array}$ & $\begin{array}{l}\text { Sensitiv- } \\
\text { ity (\%) }\end{array}$ & $\begin{array}{l}\text { Specificity } \\
(\%)\end{array}$ \\
\hline \multirow{2}{*}{$\begin{array}{l}\text { Appendix } \\
\text { diameter } \\
(\mathrm{mm})\end{array}$} & 0,994 & 6,3 & 98,1 & 100,0 \\
\hline & $(0,981-1,000)$ & & & \\
\hline \multirow{2}{*}{$\begin{array}{l}\text { Appendix } \\
\text { wall thick- } \\
\text { ness (mm) }\end{array}$} & 0,982 & 3,08 & 96,2 & 97,9 \\
\hline & $(0,953-1,000)$ & 3,20 & 88,5 & 100,0 \\
\hline \multirow{3}{*}{$\begin{array}{l}\text { Cecum wall } \\
\text { thickness } \\
(\mathrm{mm})\end{array}$} & $0,970(0,937-$ & 3,27 & 96,2 & 95,8 \\
\hline & $1,000)$ & 3,94 & 63,5 & 100,0 \\
\hline & & & & \\
\hline \multirow{2}{*}{$\begin{array}{l}\text { Bending } \\
\text { angle } \\
\text { (degrees) }\end{array}$} & 0,695 & 113,15 & 76.9 & 58,3 \\
\hline & $(0,588-0,801)$ & 110,00 & 69,2 & 60,4 \\
\hline
\end{tabular}

${ }^{*}$ AUC: Area under curve, ${ }^{* *} \mathrm{ROC}$ : Receiver operating characteristic, ${ }^{* *} \mathrm{Cl}$ : Confidence interval

There was a high correlation between two measurements of the same observer $(p<0.001$, $r=0.884)$. However, interobserver reliability was lower compared to intraobserver rates $(p=<0.001$, $r=0.262)$.

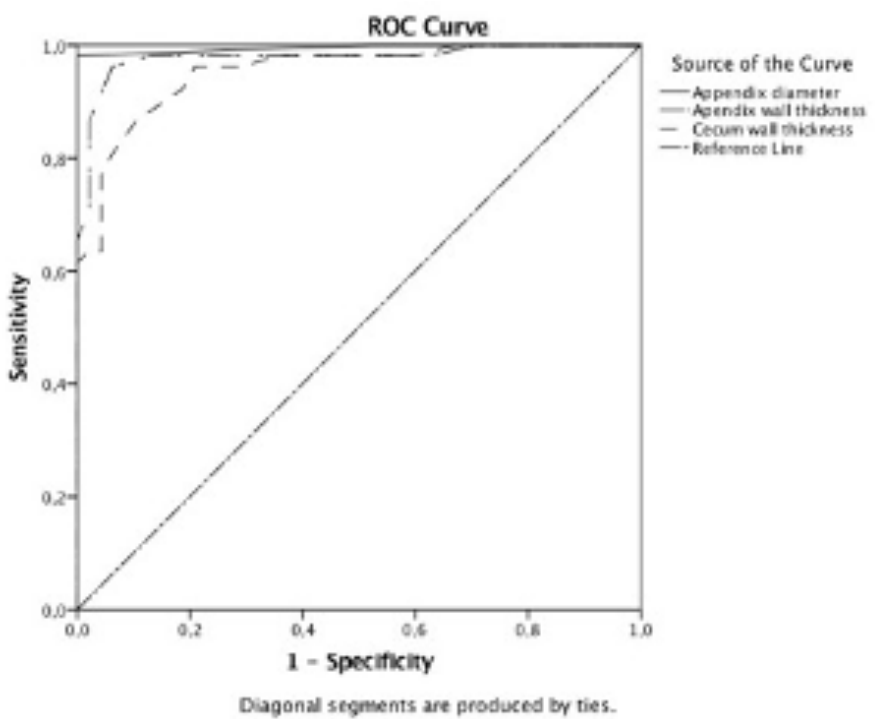

Figure 2. ROC curve of appendix wall thickness, cecum wall thickness and appendix diameter 


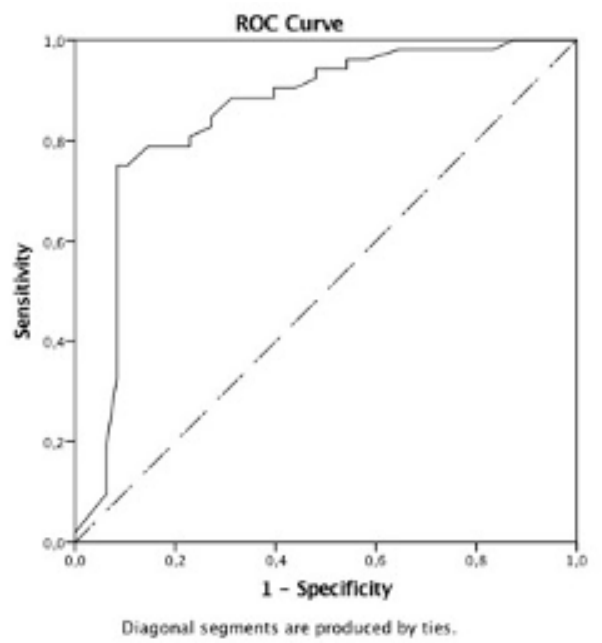

Figure 3. ROC curve of appendix bending angle

\section{DISCUSSION}

Diagnosis of acute appendicitis can be determined by observing the increased diameter of the appendix, the presence of appendicolith, peri appendiceal inflammation and free fluid on the CT [15]. Except those on MDCT, as in our hypothesis, ABA can be measured as an additional and a new solution in the diagnosis of acute appendicitis.

Firstly, if we evaluate at the classic CT findings of appendicitis, we find in our study results that are similar to previous studies, such as an increased diameter and wall thickness of the appendix, increased cecum wall thickness, the presence of appendicolith, peri appendiceal inflammation and lymph node all highly indicate the presence of appendicitis. The inflamed appendix is distended with a diameter measuring between $6-40 \mathrm{~mm}$ and a wall thickness of 1-3mm [16]. Our study revealed that the mean appendix diameter was $10,14 \pm 1,53$ $\mathrm{mm}$ in acute appendicitis group. Besides over $6.3 \mathrm{~mm}$ of appendix diameter the sensitivity was $98.1 \%$ and specificity was $100 \%$. Several studies report that the diameters of normal appendices do not exceed $6 \mathrm{~mm}[17,18]$, while others reported diameters greater than $6 \mathrm{~mm}$ even up to $10 \mathrm{~mm}$ $[19,20]$. We did not detect an appendix diameter over $6 \mathrm{~mm}$ in our control group. Additionally, we measured the mean wall thickness of appendix as $3.87 \pm 0.68$ (range 2.23-5.43) in the acute appendicitis group and $2.42 \pm 0.29$ (range 1.883.18 ) in the control group.

Appendicoliths is a rare finding of the acute appendicitis but it is associated with severe appendicitis, appendiceal perforation, recurrent appendicitis after conservative therapy or failure of antibiotic therapy [21]. The presence of appendicoliths and the location of an appendicolith at the root of the appendix were significantly associated with gangrenous appendicitis [22]. As described, appendicolith is very rare, it was observed in $9.6 \%$ of the appendicitis group and not at all in the control group. Another study has reported the frequency of appendicolith as $33.3 \%$ in acute appendicitis and never observed in their control group [23]. Peri appendiceal inflammation is one of the positive findings of acute appendicitis [24]. Tatar et al. reported that in the patients with normal appendix mild to moderate peri appendiceal inflammation frequency was $12.8 \%$ and severe peri appendiceal inflammation was $3.8 \%$; in the patients with acute appendicitis, mild to moderate peri appendiceal inflammation was observed in $30.8 \%$ of the patients and severe peri appendiceal inflammation was observed in $48.7 \%$ of the patients [23]. Our study results were similar with the previous literature: we observed peri appendiceal inflammation in $73.1 \%$ of the appendicitis group and $14.6 \%$ of the control group.

In this study, we hypothesized that ABA decreases in cases of acute appendicitis and we could not find a similar study about this angle and its association with acute appendicitis. The mean ABA in acute appendicitis was significantly lower than in the control group, which supports our hypothesis that when we come up with as an empty small intestinal segment, an inflamed appendix forms an acute angle throughout the cecum. The sensitivity of ABA was calculated as $76.9 \%$ and the specificity was $58.3 \%$ at the point of 113.15 degrees which is the best cut-off point and the specificity was $59.6 \%$ at the point of 110 degrees. There was no appendicitis case over the bending angle of 142.3 degrees. With these results, we determined that ABA can be used as a novel and additional finding which can exclude acute appendicitis over 142.5 degrees and which additionally, has acceptable sensitivity and specificity values at 113.15 or 110 degrees. Furthermore, we explained the predictive 
value of $A B A$ in acute appendicitis, which is significantly high to be used as a diagnostic tool.

Having been designed retrospectively, a limitation of this study is the low number of patients included and lack of knowledge whether the patients were in the early phases of inflammation or not. Our results should be further validated with a higher number of patients and with the addition of follow-up periods, in order to build more solid recommendations after a standardized explanation of measurement method to the observers.

In conclusion, CT is an accurate imaging modality for the diagnosis of acute appendicitis. The main purpose of our study was to determine the diagnostic value of $A B A$, which can be used as a new diagnostic finding that was found to be lower in patients with acute appendicitis. There were no cases with acute appendicitis over 142.3 degrees. But further prospective studies with patients that are conservatively followed will provide better results that can be used in clinical practice.

Funding : No funding.

Conflict of interest statement : The authors declare no conflict of interest.

\section{REFERENCES}

1. Addiss DG, Shaffer N, Fowler BS, Tauxe RV. The epidemiology of appendicitis and appendectomy in the United States. Am J Epidemiol. 1990;132(5):910-925 DOI: 10.1093/ oxfordjournals.aje.a115734

2. Allievi N, Harbi A, Ceresoli M, Montori G, Poiasina E, Coccolini F, Pisano M, Ansalon L. Acute Appendicitis: Still a Surgical Disease? Results from a Propensity Score-Based Outcome Analysis of Conservative Versus Surgical Management from a Prospective Database. World J Surg. 2017;41(11):2697-705. DOI:10.1007/s00268-017-4094-4

3. Mostbeck G, Adam EJ, Nielsen MB, Claudon M, Clevert D, Nicolau C, Nyhsen C Owens CM. How to diagnose acute appendicitis: ultrasound first. Insights Imaging. 2016;7(2):255-63. DOI:10.1007/s13244-016-0469-6

4. McDonald GP, Pendarvis DP, Wilmoth R, Daley BJ. Influence of preoperative computed tomography on patients undergoing appendectomy. Am Surg. 2001;67(11):1017-21 PMID: 11730216

5. Raman SS, Osuagwu FC, Kadell B, Cryer H, Sayre J, Lu DS. Effect of CT on false positive diagnosis of appendicitis and perforation. N Engl J Med. 2008;358(9):972-73. DOI:10.1056/NEJMc0707000

6. Kabir SA, Kabir SI, Sun R, Jafferbhoy S, Karim A. How to diagnose an acutely inflamed appendix; a systematic review of the latest evidence. Int J Surg. 2017;40:155-62. DOl:10.1016/j.jsu.2017.03.013

7. Tamburrini S, Brunetti A, Brown M, Sirlin CB, Casola G. CT appearance of the normal appendix in adults. Eur Radiol. 2005;15(10):2096-103. DOI:10.1007/s00330-0052784-z

8. Jan YT, Yang FS, Huang JK. Visualization rate and pattern of normal appendix on multidetector computed tomography by using multiplanar reformation display. J Comput Assist Tomogr. 2005;29(4):446-51 DOI: 10.1097/01.rct.0000164668.03767.53

9. Kim HC, Yang DM, Jin W. Identification of the normal appendix in healthy adults by 64-slice MDCT: the value of adding coronal reformation images. $\mathrm{Br} \mathrm{J}$ Radiol. 2008;81(971):859-64. DOI:10.1259/bjr/19297777

10. Celep B, Bal A, Özsoy M, Özkeçeci Z, Tunay K, Erşen O, Arıkan Y. Akut apandisit tanısında bilgisayarlı tomografinin yeri. Bozok Tip Dergisi. 2014;4(3):33-29

11. Simonovsky. Sonographic detection of normal and abnormal appendix. Clin Radiol. 1999;54 (8):533-39 DOI: 10.1016/s0009-9260(99)90851-6
12. Ives EP, Sung $\mathrm{S}$, McCue $\mathrm{P}$, Durrani $\mathrm{H}$, Halpern $\mathrm{EJ}$. Independent predictors of acute appendicitis on CT with pathologic correlation. Acad Radiol. 2008;15(8):996-1003. DOI:10.1016/j.acra.2008.02.009

13. Lee SY, Coughlin B, Wolfe JM, Polino J, Blank FS, Smithline HA. Prospective comparison of helical CT of the abdomen and pelvis without and with oral contrast in assessing acute abdominal pain in adult Emergency Department patients. Emerg Radiol. 2006;12(4):150-57. DOI:10.1007/s10140-006-0474-z

14. Mun S, Ernst RD, Chen K, Oto A, Shah S, Mileski WJ. Rapid CT diagnosis of acute appendicitis with IV contrast material. Emerg Radiol. 2006;12(3):99-102. DOI:10.1007/ s10140-005-0456-6

15. Bursali A, Arac M, Oner AY, Celik H, Eksioglu S, Gumus T. Evaluation of the normal appendix at low-dose non-enhanced spiral CT. Diagn Interv Radiol. 2005;11(1):45-50. PMID: 15795844

16. Rettenbacher T, Hollerweger A, Macheiner P, Rettenbacher L, Tomaselli F, Schneider B, Gritzmann N. Outer diameter of the vermiform appendix as a sign of acute appendicitis: evaluation at US. Radiology. 2001;218(3):757-62. DOI:10.1148/radiology.218.3.r01fe20757

17. Vignault F, Filiatrault D, Brandt ML, Garel L, Grignon A, Ouimet A. Acute appendicitis in children: evaluation with US. Radiology. 1990;176(2):501-04. DOI:10.1148/radiology.176.2.2195594

18. Sivit CJ. Diagnosis of acute appendicitis in children: spectrum of sonographic findings. AJR Am J Roentgenol. 1993;161(1):147-52. DOI:10.2214/ajr.161.1.8517294

19. Quillin SP, Siegel MJ. Appendicitis: efficacy of color Doppler sonography. Radiology. 1994;191(2):557-60. DOI:10.1148/radiology.191.2.8153340

20. Rao PM, Rhea JT, Novelline RA. Sensitivity and specificity of the individual CT signs of appendicitis: experience with 200 helical appendiceal CT examinations. J Comput Assist Tomogr. 1997;21(5):686-92 DOI: 10.1097/00004728-199709000-00002

21. Shindoh J, Niwa H, Kawai K, Ohata K, Ishihara Y, Takabayashi N, Kobayashi R, Hiramatsu $T$. Predictive factors for negative outcomes in initial non-operative management of suspected appendicitis. J Gastrointest Surg. 2010;14(2):309-14. DOI:10.1007/ s11605-009-1094-1

22. Ishiyama M, Yanase F, Taketa T, Makidono A, Suzuki K, Omata F, Saida Y. Significance of size and location of appendicoliths as exacerbating factor of acute appendicitis. Emerg Radiol. 2013;20(2):125-30. DOI:10.1007/s10140-012-1093-5

23. Gunes Tatar I, Yilmaz KB, Sahin A, Aydin H, Akinci M, Hekimoglu B. Evaluation of Clinical Alvarado Scoring System and CT Criteria in the Diagnosis of Acute Appendicitis. Radiol Res Pract. 2016;2016:9739385. DOI: 10.1155/2016/9739385

24. Pinto Leite N, Pereira JM, Cunha R, Pinto P, Sirlin C. CT evaluation of appendicitis and its complications: imaging techniques and key diagnostic findings. AJR Am J Roentgenol 185. 2005;(2):406-17. DOI:10.2214/ajr.185.2.01850406 